\title{
A Study of Values of Royong Verses and Their Implementation in Local Content Learning
}

\author{
Asis Nojeng \\ Universitas Negeri Makassar, Jln. Bonto Langkasa, Kampus Gunung Sari, Makassar, Sulawesi Selatan, Indonesia \\ Jufri \\ Universitas Negeri Makassar, Jln. Bonto Langkasa, Kampus Gunung Sari, Makassar, Sulawesi Selatan, Indonesia \\ Kembong Daeng \\ Universitas Negeri Makassar, Jln. Bonto Langkasa, Kampus Gunung Sari, Makassar, Sulawesi Selatan, Indonesia
}

\begin{abstract}
This research is a qualitative research that aimed to study, analyze, and implement the values contained in the royong verses of Makassar. The data obtained was analyzed by the researchers by using Semiotic analysis popularized by Michael Riffaterre. Techniques of collecting data of values and the their implementation in local content learning were interviews, recording, and library research. The results of this research revealed the values of royong verses collected by the researchers. These values were then divided into three parts, 1) Personal Values, 2) Social Values, and 3) Religious Values. The personal values include; compassion, obedience, intelligence and diligence, self-esteem, kindness, Careful speech or not inviting danger, alertness, independence, hard work, patience, Harmony of words and deeds or readiness and action, persistence or consistency, self-esteem maintenance, clever or intelligent and knowledgeable, Avoidance of despair or patience, a sense of pain, A sense of obligation; motivation, will, intention and determination, not arrogant or humble. Meanwhile, the social values consist of Thinking before doing, Honesty and true words, Obedience to parents, Belief and true character, Upholding dignity and prestige, participative, responsive to the environment. The third values, religious, include Faith, devotion and obedience to One Almighty God, Power of effort and plea to One Almighty God, Fate or surrendering to the absolute will of the Creator. These values were then implemented in the local content learning in elementary schools (SD) located in Takalar regency.
\end{abstract}

Index Terms - values, implementation, oral literature, royong

\section{INTRODUCTION}

According to Taum (1997, p. 13), literature refers to imaginative works or fiction, or the use of a beautiful and useful language that signifies other things. Mursal Esten (1978, p. 9) argues that Literature is the disclosure of artistic and imaginative facts as the manifestation of human life (and society) through language as the medium and has positive effects on human life (humanity).

Teeuw (Endraswara, 2011, p. 151) holds that oral literature is still present in various corners of society. Oral literature found in remote areas is usually purer because people in these areas are not familiar with technology and are also illiterate, compared with oral literature in the midst of urban society where oral literature is just like "unclear sounds" because it is shifted by the technological sophistication and the influence of foreign cultures.

According to Endraswara (2011, p.150), studies on oral literature is in need of precision and thoroughness. Therefore, sometimes some oral literatures are pure and some are not pure. Pure oral literatures, for example, are fairy tales, legends, myths, or stories spread orally in society. Oral literature that is not pure usually mingles with oral tradition in society. This mingled oral literature is sometimes only a fragment of sacred stories. It may be that the story only comes from incomplete ancestral traditions.

The forms of oral literature are prose (eg, myths, fairy tales and legends), folk poems (such as verse, gurindam, and pantun), performing arts such as wayang, traditional expressions (sayings and proverbs), folk songs, etc. The development of oral literature in Indonesian literature is influenced by several foreign cultures, such as Chinese culture, Hinduism and Buddhism, Indian culture, and Arabic culture. The oral literature influenced by these cultures was brought by way of trade, marriage, and religion.

The function of oral literature is not merely a need of art, but there is also education to be conveyed therein, such as moral values and religious values in society. One oral literature pertaining to morals is royong. Royong is an oral literature containing life advices.

Philosophically, the importance of research on the implementation of royong values is based on three main aspects, the ontology, axiology and epistemology. Ontologically, royong in Makassarese community is a literary work in the form of lyrical prose the presentation of which is in the form of songs. 
The expression of oral literature in society is always carried out with amazing passion and creativity, which of course is aesthetic, symbolic, and metaphorical. Originally, literary forms were folk tales delivered orally from mouth to mouth and from generation to generation (Ikram 1997, p. 220), which then evolved into various forms such as poetry, lyrical prose, songs, and so on.

Axiologically, the spread and inheritance of oral literature is usually done through oral tradition or by an example accompanied by gesture and memorization from one generation to the next. Thus, oral literature in its development has become the result of a traditional culture.

This oral literature has special features that distinguish it from written literature. Amir (2013, p. 78) explains that the characteristics of oral literature include: (1) oral literature exists in the form of performances, in many cases accompanied by musical instruments, even dances, (2) entertainment and education are dominant elements in it, (3) oral literature uses local or regional languages, at least regional dialect, and (4) oral literature uses the poetry of the concerned speech community.

In addition, Ansor et al (2007, p. 2) defines oral literature as one part of the oral tradition. Oral literature is spread from one person to another, so the oral tradition develops in the middle of the community by using language as the main medium.

Furthermore, Nursito (2000, p. 114) explains that oral literature belongs to the old literature. The general characteristics of the old literature are; (1) in line with the attitude of the conservative and traditional society, which means that the old literature is static, 2) the old society prioritizes mutual cooperation. Therefore, the old literature as a product of society is owned together. That is why the poets do not want to accentuate his name and announce his work to the community.

Hutomo (1991, p. 3) states that oral literature has some features, among others; 1) spread from mouth to mouth, the expression of culture spread in terms of time and space is transmitted by word of mouth, 2) born from a village-based society, out-of-town community, or illiterate society, 3) describing the cultural characteristics of one society for oral literature is a cultural heritage that portrays the past, but also mentions new things (according to social issues), therefore oral literature is also called living fossil, 4) poetic, 5) consisting of various versions, 6) not emphasizing the fact or truth, but emphasizing the fantasy aspect, which is not accepted by modern society, and, however, having functions in society, and 7) using everyday oral language.

According to Sudardi, (2002, p. 2) in the communication of oral literature, there are four important elements to achieve such communication. These four elements of communication must be present simultaneously in the presentation of oral literature. Those four elements are: (a) artist, (b) story, (c) performance, and (d) audience.

In addition to oral literature, in society there is also oral tradition which in its development follows the social condition of the society. According to Pudentia (2008, p. 377), oral tradition in its various forms is very complex and contains not only stories, myths and fairy tales, but also contains various things concerning life and the life of the community such as local wisdom, value system, belief and religion system, as well as various art products.

Oral literature is part of the culture of Indonesian archipelago of which existence fades because oral literature is only used by certain people who know and understand oral literature. This will be one of the reasons that oral literature will become extinct if there is no attempt by the younger generation or caring people to preserve it. Learning and research in conservation efforts for oral literature both through non-formal and formal education are also far beyond the expectation.

This axiological reality shows a gap between the expectation and reality; between the cultural heritage and the works of oral literature and the reluctance to preserve these works of oral literature.

This is what inspired the researchers to choose one oral literature as an effort to introduce and preserve the oral literature for the younger generation, for education, and for the Indonesian archipelago. The researchers also realized that what they did by trying to select one of the oral literatures to be investigated in the effort of preservation was also still relatively simple. However, the researchers assumed that nothing is worthless as long as there are intention and effort towards preservation and improvement. Therefore, this research is an effort to contribute to the preservation of oral literature especially Makassarese oral literature, royong.

Preservation of oral literature also faces obstacles because in order to be able to understand and interpret an oral literature it requires an effort that is not easy. Besides knowing the texts of oral literature structurally, understanding and interpretation also require some elements and things that are beyond the texts of oral literature. This is what makes people sometimes feel reluctant to learn oral literature. All this time, oral literature especially certain oral literatures like gotong is only considered as a tool or medium for the sake of community traditionally, for example, as a tool for wedding ritual, for putting child to sleep, for worship, and others. This assumption will ultimately make oral literature less introduced and taught in formal education. It is also because oral literature like royong in its use is not done arbitrarily or in other words the use of oral literature royong has requirements that must be met both by the performers of royong and by those who need royong.

Oral literature in one area has meaning that is always different from other areas. Oral literature usually uses the language that refers to connotative meaning, so that oral literature is often difficult to interpret. The interpretation of the oral literature such as gotong can not be done only by referring to its text alone.

The interpretation must involve the performers of royong (paroyong) and those who understand royong. This also sometimes causes reluctance to undertake research in order to preserve oral literature. 
There is a habit that is often done by mothers in Makassar before putting their babies to sleep. They will sing a bedtime song, sung without a musical instrument with certain verses in Makassarese language while the baby is swinging slowly until his/her eyes are closed. This song among Makassarese people is called royong.

Epistemologically, beside being understood as a form of artistic or rhythmic oral literature, royong is also known to have social and cultural functions in its supporting community. Royong in Makassar tradition is sacred. In essence, royong constitutes a typical traditional prayer presented in the form of singing (vocal music) and contains religious symbolic values. As a prayer royong for Makassarese people is a mystical institution (Sulkarnaen, 2010, p. 86).

Royong is considered to have a very important role and function, so it is always presented and becomes part of a ritual performed. Royong is believed to connect the human world and the unseen world (Sulkarnaen, 2010, p. 18). Makassarese people believe that royong can keep danger and evil spirits away (Solihing, 2004, p. 4).

\section{METHODOLOGY}

This research is a qualitative research with descriptive method. In accordance with Bogdan and Taylor (in Moleong, 2005 , p. 4), qualitative research is a research procedure that produces descriptive data in the form of written or spoken words of people or the performers of royong that can be observed. Data of this research consists of primary data and secondary data. According to Umar (2003, p. 56), primary data refers to data obtained directly by the reearchers as an object of writing. In-depth interviews were used to obtain data from the informants to be interviewed. Interviews that were conducted by the researchers were the interviews with the use of guidelines (interview guide) for more in-depth interviews focusing on the issues investigated. Interview guidelines do not usually contain detailed questions, but merely an outline of what kinds of data or information to collect from the informants. Meanwhile, according to Sugiyono (2005, p. 62) secondary data refers to data that are not directly provided to the researchers that, for example, a research must be conducted through people or document searching. This kind of data is obtained using literature study conducted on many books and obtained on the basis of notes relating to research. In this study, the researchers acted as a single instrument.

\section{RESULTS AND ANALYSIS}

In this chapter, the researchers describe the results of the research in the form of data analysis and discussion based on the semiotic analysis popularized by Michael Riffaterre. The data analysis was conducted to determine values contained in the royong verses spread in several regencies in South Sulawesi.

\section{A. Results on Values of Royong Verses}

The values contained in the text of royong that have been collected by the researchers are as follows; Cui royong Cui Nilakborok verses contains religious values (Power of efforts and pleas to One Almighty God) including 'holy spirit please come over to this child born out of happiness, I give you (addressed to the child) a prayer and make you a source of medicine'. Furthermore, royong verses sung by Hj. Siyang Daeng Saga contain personal values consisting of a) compassion 'Grow up to be an adult with establishment my son. May you have a long life and have happiness. I hope you share that happiness with me too', b) intelligence and diligence 'If you later grow up and become an established person, enrich your knowledge. Hopefully, you will have much knowledge a provision for yourself ', c) clever or intelligent and knowledgeable 'If you grow up, I will recommend you to recite the Koran. May you finish your recitation and also finish your school'. The next value is the social value that includes Obedience to parents' Grow up to an adult with establishment my son. May you have a long life and have happiness, I hope you share that happiness to me too'. The next value is the religious value (Power of efforts and pleas to One Almighty God) 'To all Angels and to forty Walis, please help my son. Unite his soul with his body so that he can sleep soundly tonight'.

The next values are derived from the royong verses sung by Chaeruddin Hakim. The personal values in it include, a) compassion 'My son, even though your food is gold and diamond is its side dish, remember my son the sacrifices your mother has done to you', b) Careful speech or not inviting danger, and alertness 'May you be happy my son, do not hurt others' feeling, do not pick a quarrel with anyone. I only ask one thing, may you be happy', c) independence 'Thou shalt not humiliate yourself, it is humiliating to expect compassion from others', d) a sense of pain 'You are my son. A child who grows self-esteem, shame and pain you cultivate in you', e) A sense of obligation; motivation, will, intention and determination 'I hope you are happy my son, may you have all the joy so that your shoot and stalk also feel the happiness'. The next is the social value which consists of a) Honesty and true words 'You are my son. Have good manners, be noble-hearted. Be polite to everyone', b) upholding dignity and prestige 'you are my son, from the very topmost place, born from the the land full of traditions, uphold the traditions', c) participative 'You are my son, from the topmost place, missed by many people. May you be happy and remember those in difficult situations', d) Responsive to the environment 'You are my son, son. Be courteous and friendly to your neighbors'.

The next verses of royong are sung by $\mathrm{Hj}$. Syamsiah of which personal values consist of a) Obedience 'Who makes Aco cry loudly?, his own mother for not being obedient', b) self-esteem 'Although your pole of your house is gold, even though the stairs are diamond I will not go upstairs if iI am disappointed and My anger has culminated', c) patience 'because of my poverty, I have my feelings strengthened, even though I am given feeling of blandness, I still make 
sweetness happiness', d) Avoidance of despair 'I have been driven out by disappointment and anger, But I am still here waiting for happiness', e) Not arrogant or humble 'I am not gold or sparkling diamond, I am only brass but can not be tested'. The next values are social values (thinking before doing) 'Regret is like that, never at the beginning, always comes last with a state of astonishment'. Religious values (faith, devotion, and obedience to One Almighty God) 'I surrender everything to my Lord, and I make Prophet Muhammad my strongest fence'.

The Next is the values contained in the royong verses sung by Daeng Sakking. Its personal values include; A) Kindness 'Oh my dear, grow up to be a kind person, and also be kind to others', b) Harmony of words and deeds or readiness and action 'Oh my Lord, make my son a good man, make him a golden child, make him follow your orders, strengthen his soul, strengthen his words as well. My son is a good boy'. The results of the analysis of the next royong values came from Kartini Daeng Caya. The values found include; Personal Value a) Hard work or work ethic 'Though on the highest mountain', b) Persistence or consistency 'He will climb because there is happiness above it'. The next values are social value (belief and true character) 'May happiness be granted by Allah SWT.' The next is religious value (Power of efforts and pleas to One Almighty God) 'Obtaining blessings from Allah SWT.

\section{B. Implementation of Values in Local Content Learning}

Based on the analysis of royong verses, the values that can be implemented in local content subject in elementary schools. However, the researchers only selected some schools located in Takalar regency. These schools were State Primary School (SDN) Number 31 Lau, State Primary School (SDN) number 139 Inpres Benteng Sanrobone, and SDN State Primary School (SDN) number 194 Inpres Taipanorang.

The values of royong verses in local content learning were determined by the researchers to be implemented in higher grades; grade four (4), five (5) and six (6). The following are the explanations of values that can be implemented in local content subject.

Personal value (harmony of words and deeds) in royong verses sung by Daeng Sakking is 'Oh my Lord, make my son a good man, make him a golden boy, make him follow your orders, strengthen his soul, and strengthen his words. My son is a good boy'. This value can be implemented in local content subject written by Fattah Tika in 2005 page 10 at State Primary School (SDN) Number 31 Lau Sanrobone subdistrict Takalar regency for fourth grade (4); 'speaking politely'. The hope desired by the royong performer and the author of the book is to make children adhere to his words and speak politely.

Social value (thinking before doing) in royong verses sung by $\mathrm{Hj}$. Syamsiah stanza 23 'Regret is like that, never at the beginning, always comes last with a state of astonishment' can be implemented in local content subject written by Kembong Daeng in 2012 page 15 at SD Negeri Number 139 Inpres Benteng Sanrobone Sanrobone subdistrict Takalar regency for fifth grade; 'Quickly repent before you die, Do not regret until death comes to you.

Personal values (Honesty and True Words) sung by Chaeruddin Hakim stanza 12 'You are my son. Have good manners. Be noble-hearted. Be polite to everyone' can be implemented in local content subject written by Fattah Tika in 2008 page 16 at State Primary School (SDN) Number 194 Inpres Taipanaorang North Galesong subdistrict Takalar regency for sixth grade; 'Forgive me if my words offensive to you.

\section{DisCUSSION AND CONCLUSION}

This study used semiotic analysis to find meaning and values contained in the text of royong that have been collected by the researchers.

Hermeneutic reading helps the researchers or the readers in interpreting, here are some examples of hermeneutic reading;

May you repay me (with) sweetness (royong text of Daeng Sakking stanza 2). The expectation of a mother is not when her child grows up she gives him/her sugar or anything that tastes sweet, but Tekne or 'sweet' in question is that the child repays his/her mother who has given birth to, nurtured and raised him/her.

Giving something sweet is a representative of the word 'happiness', but the royong perfomer or paroyong does not explicitly convey this meaning to the listeners or the child. This proves that the text of royong requires a second level of reading known as hermeneutics (retroactive).

After doing a second level of reading, to get the values contained in the text of royong the researchers used cultural Taxonomy. Jufri (2007, p.122) formulated three aspects of value with several indicators called cultural value model that can be used as a reference for research on flexible culture. These three aspects of value are (1) personal value, (2) social value, and (3) religious value.

The values that the researchers have found are consistent with what is in the textbook of local content subject. The existing values apparently can be implemented in local content subject. The following are some examples of values implemented in local content subject.

Personal value (Obedience) can be found in the text of royong sung by Hj. Syamsiah; 'Who makes Aco cry loudly?, his own mother for not being obedient'. This value can be implemented int Local content subject in the textbook entitled Lontarak Gowa Basa Mangkasarak for elementary school students grade 4 (four) material Kana Alusuk (subtle words), sub-material Paruntuk Kana (Proverb), 'Listening to Words' (Tika 2005, p.23). This value encourages us to keep 
listening to words or commands from people older than us, especially from our parents. Listening to words means refers to someone who obeys commands.

Based on the results of this research and the discussion of the values of royong verses in local content learning, the researchers have comme to the conclusions that:

First, based on the results of the analysis or heuristic reading, it was found the meaning of the first word of the text or royong verses sung. The first meaning provided by the researchers proved that there are some royong verses that have meanings but have not been revealed. Therefore, the researchers performed a second level of reading or commonly called hermeneutics/retroactive. Meanings that have not been revealed in the first reading were revealed in this second level of reading. However, the second level of reading was not separated from the meaning to be conveyed by the performer of royong and the researchers' interpretation.

Second, the results of data analysis or the first reading (heuristic) and the second reading (retroactive/hermeneutic), revealed the values contained in the royong verses. The values found were determined by using cultural Taxonomy. These values are; a) Personal values consisting of compassion, obedience, intelligence and diligence, precision, selfesteem, honesty, courage, careful speech, independence, hard work, patience, perfection of life, harmony of words and deeds, persistence, keeping promises, self-esteem maintenance, clever, avoidance of despair, dedication, firmness, and not arrogant. b) Social values consisting of thinking before doing, generosity, carefullness in earning a living, compassion, togetherness, honesty and true words, freedom, obedience to parents, fairness, belief and true character, communicative in seeking the truth, Accepting the views of others, upholding dignity and prestige of the family, participative, solidarity, responsive to the environment, responsibility and affection, not quickly believing information from others. c) Religious values consisting of immortality, majesty, greatness, Faith, devotion, and obedience to One Almighty God, Power of efforts and pleas to One Almighty God, nobleness, honor, and holiness.

Third, the values found in the royong verses were then implemented in the local content subject. In this research, the researchers selected three elementary schools in Takalar regency. These schools are; A) SDN State Primary School (SDN) Number 31 Lau Sanrobone sundistrict, b) State Primary School (SDN) Number 139 Inpres Benteng Sanrobone Sanrobone subdistrict, c) State Primary School (SDN) Number 194 Inpres Taipanaorang North Galesong subdistrict. However, in this research, the researchers only took higher grades, namely fourth grade, fifth grade, and sixth grade. In accordance with the initial observation conducted by the researchers, the values contained in the royong verses are highly suitable to be implemented in higher-grades.

\section{REFERENCES}

[1] Amir, Adriyetti. (2013). Sastra Lisan Indonesia. Yogyakarta: Andi Ofset

[2] Ansor, Muhammad dkk. (2007). Sastra Lisan Koba Rokan Hulu. Pekanbaru: Depdikbud Prov. Riau.

[3] Endraswara, Suwardi. (2011). Metodologi Penelitian Sastra. Yogyakarta: CAPS

[4] Hutomo, S.S. (1991). Mutiara yang Terlupakan: Pengantar Studi Sastra Lisan.Surabaya. Hiski Komisariat Jwa Timur.

[5] Ikram, Achadiati. (1997). Filologi Nusantara. Jakarta: Pustaka Jaya

[6] Moloeng, lexy J. (2004). Metode Penelitian Kualitatif. Bandung: Rosda.

[7] Nursito. (2000). Ikhtisar Kesusastraan Indonesia. Yogyakarta: Adicita.

[8] Pudentia. (2008). Metodologi Kajian Tradisi Lisan. Jakarta: Asosiasi Tradisi Lisan

[9] Sudardi, Bani. (2001). Dasar-dasar Teori Filologi. Surakarta: Badan Penerbit Sastra Indonesia Fakultas Sastra Universitas Sebelas Maret.

[10] Sugiyono. (2005). Metodologi Penelitian Administrasi. Bandung: Alfabeta.

[11] Sulkarnaen, Andi. (2010). Tradisi Royong Kajian Terhadap Perubahan dari Ritual keseni Pertunjukan. Bandung: UPI Press

[12] Taum, Yoseph Yapi. (1997). Pengantar Teori Sastra: Ekspresivisme, Strukturalism, Pascastrukturalisme, Sosiologi, Resepsi. Ende: Nusa Indah.

[13] Umar, Husen. (2003). Metodologi Penelitian: Aplikasi dalam Pemasaran. Jakarta: Gramedia Pustaka Umum.

Asis Nojeng was born on March 11, 1985 in Jene, Takalar Regency. He was the son of Ahmad Nojeng and Siyang. He completed ELEMENTARY education in 1997, SMP 1 Mapsu 2000 Takalar, SMA Negeri 3 in 2003. Holds a Bachelor of education the Faculty of language and Literature Courses, Arts Indonesia (2008), the Makassar State University in 2008 and her master of education courses language and literature University of Muhammadiyah Makassar Indonesia in 2012.

The author is a Presenter at PT. Fajar Makassar television (2008 to the present), lecturer at the University's Foundation remains Muahammadiyah Makassar (2015 to the present), the announcer at PT. Radio Gamasi Jaya (2015 to the present).

Jufri was born in Soppeng, South Sulawesi, on 31 December 1959. He earned a Bachelor's degree (Drs.) language education Germany, in 1984. Master of education (m. Pd) taken from Malangs State University Graduate Program in 1986 (completed one year 11 months) in Indonesian Language Education debngan the title of the thesis: analysis of the reading Exercise Book KD.

A doctoral degree (Dr.) 63rd from Stanford University PPs in 2006 (completed two years, 11 months), the title of the dissertation Structure Discourse Lontara La Galigo has to be tested in front of the examiners Board of graduating with praise (Honors). Since 1985, he as an educational effort in the Department of foreign languages FPBS, IKIP Ujung Pandang (Makassar UNM now). The functional position since 2002 is Associate Professor (IV/c), with full authority and lecturing and examining one of the courses, 
namely: language learning Research (Sprachlehr-Und Lernforschung) in the Department of Foreign Language Education (Germany), the Faculty of languages and the arts, State University of Makassar. He has attended Germany language education (Sprachkurz) in Iserlohn Jermah 1987 and had been the Trainer (ToT) on HUMAN RIGHTS of members of the NATIONAL POLICE (POLRI Headquarters cooperation, UNHCR and the Department of Justice and HUMAN RIGHTS) in South Sulawesi, 2001/2002. In addition, he was the Secretary of the Department of Education language of Germany, head of the laboratory of language Germany, Secretary of the IGBJI of South Sulawesi. He was also active as a publisher of papers/participants on various national and international seminars and has written a book entitled principles of language learning Strategies.

Kembong Daeng, born on June 26, 1964 in Bontolebang, South Polombangkeng, Takalar Regency. She is the third child of three brothers of Campa Daeng Sewa and Hatijah Daeng Memang. She completed ELEMENTARY education in 1977, SMP 1 Takalar in 1981, and the SPGN Pattallasang in 1984. Holds a Bachelor of education in Indonesian Language IKIP Ujung Pandang on December 24, 1981 and a master's degree in the Humanities at the Graduate School of University of Hasanuddin on 29 February 1996.

The author is Lecturer at the Department of language and literature faculty of Indonesia and regional language and art of Makassar State University since March 1989 to the present. He is also active in conducting research activities, community service, seminars and penatar Discussed Indonesia and literature for teachers of JUNIOR HIGH SCHOOL and high school. The experience taught courses Makassar. Literary Appreciation and Makassar in the Makassar State University became the inspiration for the writing of textbooks of language areas. 